\title{
境界首内に立てられた平板置*
}

\author{
喜多義範*1, 高橋努*2, 河本 浩 明*3 \\ 広瀬幸治*4, 山本 恭二*1
}

\section{A Flat-Plate Wing Standing on a Wall Covered with a Thick Boundary Layer}

Yoshinori KITA, Tutomu TAKAHASHI, Hiroaki KOUMOTO, Kōji HIROSE, and Kyōji YAMAMOTO

Pressure distribution on a flat-plate wing surface along the chord is measured in many spanwise positions from the root of the wing, which is immersed in the wall boundary layer, to the wing section far from the wall. The flow near the root of the wing is visualized by the smoke wire method. Two kinds of secondary flow are observed at the junction between the wall and the wing: one is produced by the interaction between the wall boundary layer and the wing; and the other is induced by a static pressure difference between the wall and the suction surface of the wing. With an increasing angle of attack, flow on the suction side of the wing separates from the wing surface. But the two kinds of secondary flow suppress the separation of the flow near the root of the wing. This causes wing characteristics to improve.

Key Words: Blade, Flat-Plate Wing, Pressure Distribution, Separation, Boundary Layer, Secondary Flow, Wing Characteristics.

\section{1. 緒}

近年の航空機では，運動性能を高めるため，反りの ない薄翼で低綎横比のカナード翼が使用されている。 このように，翼の縦横比が小さくなると胴体の境界首 や翼端の随伴渦が䵝に及ほす影響が大きくなってく る.

二次元筫については古くから十分研究が行われ，紧 端の随伴渦についてもよく研究(1)されている.しかし， 境界居が買性能にどのような影䇾を及ほすかはまだ十 分に研究されていない. 特に縦横比の小さな兴では， 境界首内での置性能は二次元翼と比べどの程度か，ま た，翼端や境界層の影響が相互に干涉した場合翼性能 がどのように変化するかを，研究していく必要があ る.

本研究では，まず境界首が翼性能にどのような影響 を及ぼすかを調べる，用いた基形は基本的な翼形の平 板裂で，境界層厚さは翼弦長とほほ等しくし，迎之角 を変え翼表面の圧力分布を詳細に測定し，圧力係数な

*平成 2 年 3 月 10 日 中国四国支部第 28 期絰会講演会にお いて言演, 原稿受付 平成元年 9 月 4 日.

*1 正員. 岡山大学工学部 $(800$ 岡山市津島中 3-1-1).

*2 学生员, 岡山大学大学院.

*3 岡山大学大学院.

*4 正員，岡山理科大学工学部（-700 周山市理大町 1-1).
どのスパン方向分布を求めた。なお，翼形の影響や翼 端と境界層とが干涉した影響については次報で報告す る.

\section{2. 实検装置およひ実跧方法}

境界唐内に立てられた平板翼の実験を行うに当た り，風洞の測定流路側壁面上の境界首を利用する。そ の供試低速風洞および測定流路の概略を，図 1 に示 す.

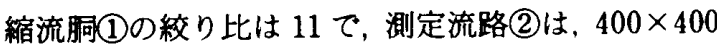
$\mathrm{mm}$ の正方形断面で長さ $4350 \mathrm{~mm}$ である. 平板翼(5) は，測定流路入口から下流 $1980 \mathrm{~mm} て ゙$, 側壁面中央 にターンテーブル(6)を介して取付けられている．主流 の静圧 $p_{0}$ は，置取付位置前方 $310 \mathrm{~mm}(\fallingdotseq 5 C)$ の側壁 面中央に設けた静圧孔(4)で测定した。なお，平板翼取 付位固における側壁面上の速度境界首厚さ $\delta$ を厚く する際には，トリッピングロッド(3)を平板翼を取付け る予定の側壁面側に取付けた。

本報告に用いた座標系を，図 2 に示す。原点Oを翼 前縁と測定流路側壁面の交点にとり, 主流方向に $X$ 軸, 翼スパン方向に $Y$ 軸, $X-Y$ 平面に垂直に $Z$ 軸 をとる．また，平板翼面上においては，翼弦方向に $\xi$ 軸, 翼表面の法線方向に $\eta$ 軸をとる. 
実験に用いた平板翼の構造を，図 3 に示す。翼は，長

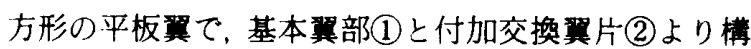
成される，基本望部(1)は，外径 $1.2 \mathrm{~mm}$ の細管(5)を 50 本含有し, 翼弦長 $C$ は $63 \mathrm{~mm}$, 翼厚 $t$ は $3.2 \mathrm{~mm}(t / C$

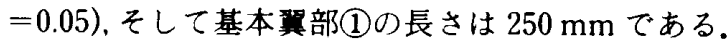
翼面静圧孔(3)の直径は $0.8 \mathrm{~mm}$ であり，片方の翼表面 だけに基本翼部翼端から翼根元のほうへ $48 \mathrm{~mm}$ およ び $60 \mathrm{~mm}$ (約 $0.8 C$ およびC) 離れた所で，それぞれ翼 弦方向に 25 個ずつ, 合計 50 個設けられている. 翼表 面の圧力は，基本翼内のこれらの細管から多管液柱計 に導かれて測定される。

付加交換翼片(2)は，基本翼部(1)の翼端に取付けられ て, 翼長さを流路いっぱいの $H=400 \mathrm{~mm}$ とし, 中央 では翼を二次元翼とみなせるようにした。そして，基 本翼部(1)を流路内に次第に挿入することにより，压力 測定孔の位置 $Y$ を翼根元からスパン方向へ $12 \mathrm{~mm}$ $(\fallingdotseq 0.2 C)$ 間隔で $Y=168 \mathrm{~mm}$ まで変化させた。また， 圧力測定孔は前述のように翼表面の一方にしか設けら れて扮らず，正圧面と負圧面の圧力分布の測定には置 を $180^{\circ}$ 回転させることにより行った。

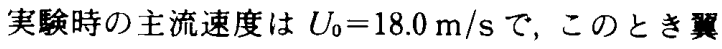
弦長 $C$ を代表長さとするレイノルズ数は $R e=7.7 \times$ $10^{4}$ である。圧力分布の測定は，二次元置の翼性能を求 める際は, 境界層厚さ $\delta=28.6 \mathrm{~mm}$, 圧力測定位置は $Y=168 \mathrm{~mm}(\fallingdotseq 2.8 C)$ で行った。境界層が翼性能にど のような影響を及ぼすかを調べる際は境界層厚さ $\delta$ を $59.8 \mathrm{~mm}$ と厚くし，圧力測定位置を $Y=0.4 \sim 144$ $\mathrm{mm}(\fallingdotseq 0.007 \mathrm{C} \sim 2.4 C)$ まで変化させた。この厚くした 境界層内の速度分布 $U / U_{0}$ は, $1 / 8$ 乗則に一致し, 形 状係数は約 1.3 であった。 そして, 内層領域で Coles ${ }^{(2)}$ が提唱する数值を用いた壁法則と一致し，乱れ分布は Klebanoff らの赛験結果とほほ一一致した。なお，測定 流路断面中央の乱れ強さ $u^{\prime} / U_{0}$ は $0.3 \%$ あ゙あた。こ れらのことから，この厚くした境界居は平滑平面上で

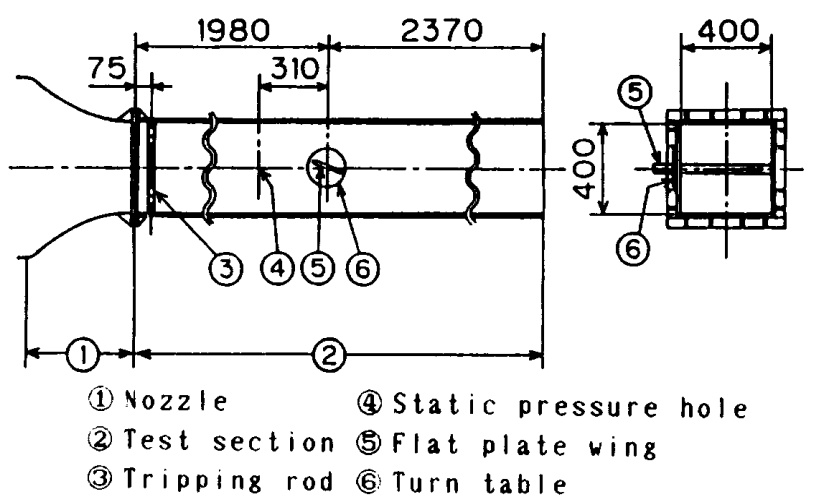

図 1 実験装荁
発達した普通の乱流境界届であることがわかる。

また，買負圧側根元付近の流れの詳細をスモークワ イヤ法を用いて観察した。

\section{3. 実検結果およひ教宗}

$3 \cdot 1$ 二次元平板罢側壁面の境界屏内に立てら れた平板翼周りの流を調べる前に，基本となる二次元 置の翼性能を調べる。

迎え角 $\alpha$ で測定された圧力 $p$ から，局所圧力係数

$$
C_{p}=\frac{p-p_{0}}{\frac{1}{2} \rho U_{0}^{2}}
$$

を求め，その值を累弦方向に積分して圧力係数

$$
C_{N}(\alpha)=\int_{0}^{1} \frac{p-p_{0}}{\frac{1}{2} \rho U_{0}^{2}} d\left(\frac{\xi}{C}\right)
$$

を求めた。この $C_{N}(\alpha)$ 值を用いて，置表面摩擦を無視 して, 揚力係数 $C_{L}=C_{N}(\alpha) \cos \alpha$ および抗力係数 $C_{D}$ $=C_{N}(\alpha) \sin \alpha$ とした.

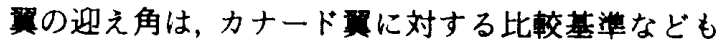
考え0 90 と弯化させた. 迎え角に対する $C_{N}(\alpha), C_{L}$, $C_{D}$ の変化の様子を図 4 に示す. 図 4 中の一点鎖線は, 二次元平板翼理論から導いた揚力係数 $C_{L}=2 \pi \sin \alpha$ である、まず, $\alpha=90^{\circ}$ の $C_{N}(90)$ は 2.55 であり、これ

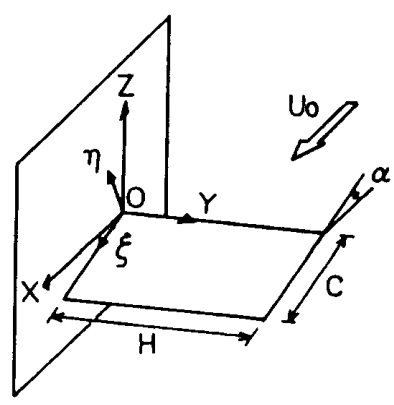

図 2 座栖系

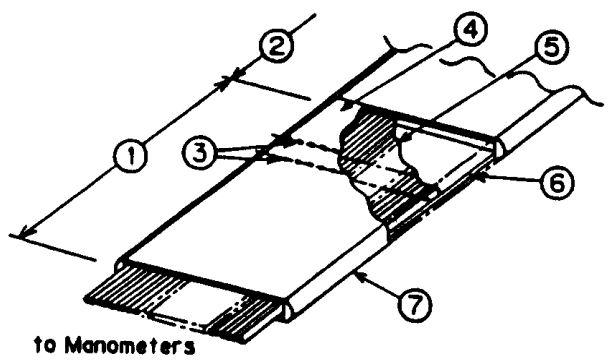

(1) Base wing (4) Acryl plate

(2) Extended wing (5) Stainless steel pipe (3) Pressure hole (6) Aluminium plate

$(\phi 0.8 \mathrm{~mm}, 2 \times 25)(7)$ Semicircular blass bar 図 3 平板翼の槽造 
は他の実耠値 1.98〜2.05 正しく測定されたかを確かめるため置弦方向の圧力分 布を調べた，置正圧面側では $C_{p}=1.0$ となる所が中央 近くに存在し，また流速を 3 種類変えても基正，負圧 面上の $C_{p}$ 分布に差異はなかった。これらのことから， $C_{N}(90)$ 值 2.55 は信頼できる值と判断される.

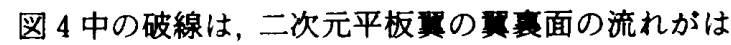
く雖していると仮定して導いたキルヒホッフの理論 式(4)による $C_{N}(\alpha) / C_{N}(90)$ の理論值に, 実測した $C_{N}(90)$ 值 2.55 を乗じ，少し無理だが $C_{N}$ の変化の様 子を示した。 $C_{N}(\alpha)$ 分布の形が破線とよく似ているの がわかる．また， $C_{N}(\alpha)$ は，迎え角が大きくなるとと

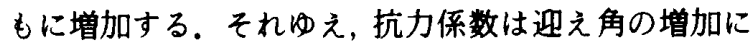
伴い増加する。一方，揚力係数は小さい迎え角 $\left(0 \sim 6^{\circ}\right)$ の観讲で，実測値と理論值はよく一致する。しかし， $\alpha$ $=8^{\circ}$ 以上の迎え角では，翼表面の流れがはく離するた め $C_{L}$ の実測值と理論值は一致しない。そして, 揚力 係数は $\alpha=45^{\circ}$ の 1.3 まで増加するが，それ以後では 減少する。

なお，本節での二次元重の実測值には添字 2 をつけ て表し，3.2 節以後での境界層の影整のある場合の実 測值との比較の基準とする.

$3 \cdot 2$ 圧力係数分布 責表面の圧力分布に, 筫根 元の境界層がどのような影签を及ほすかを調べる。

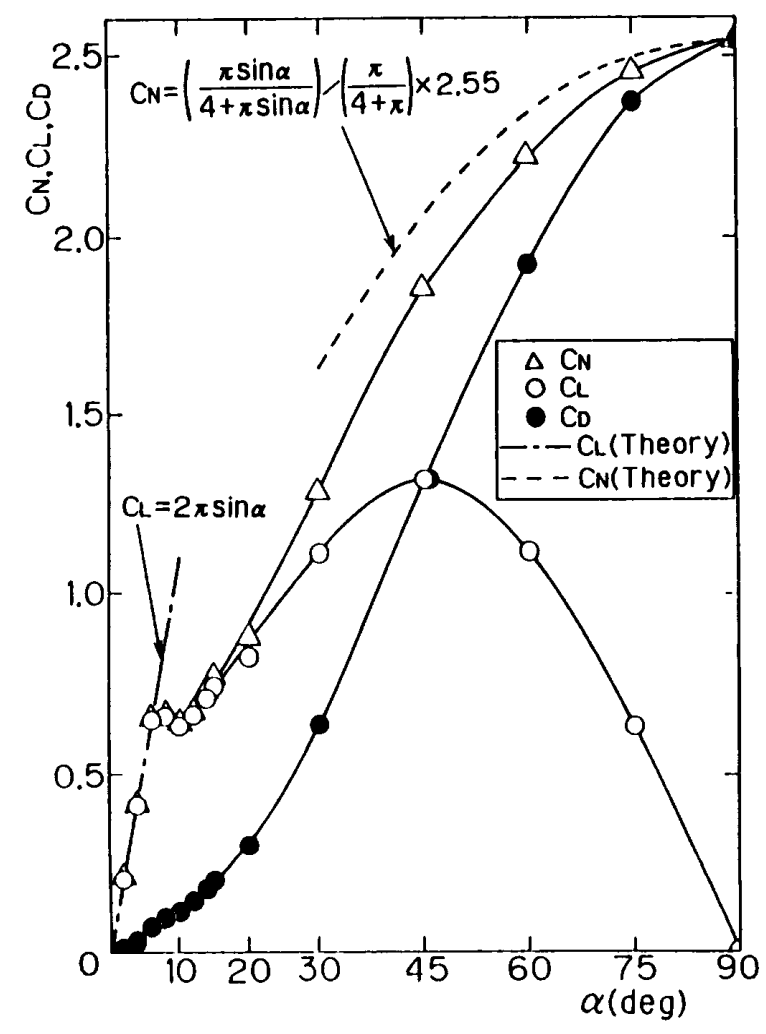

図 $4 C_{N}, C_{L}, C_{D}$ 值
測定した基表面の圧力から，二次元筫の場合と同様 に, 局所圧力係数 $C_{p}$ および圧力係数 $C_{N}$ を求めた。こ の $C_{N}$ のスパン方向の分布を， 3 種の迎え角に対して 図 5 に示す。横軸は策根元からの距離 $Y$ を真弦長 $C$

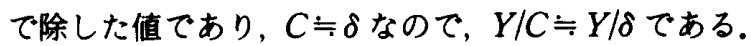

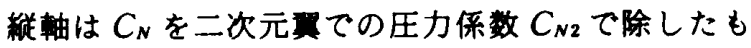

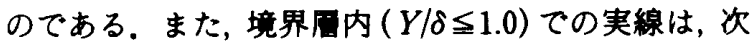
のようにして求めたものである.

二次元罢においては，代表速度に一様流速 $U_{0}$ を用 いて $C_{N}$ を求めた $[$ 式(1)]。しかし，境界庴内では流 速 $U$ は式(2)のような速度分布を持っていた。

$$
\frac{U}{U_{0}}=\left(\frac{Y}{\delta}\right)^{1 / 8}
$$

境界層内のある圧力測定位置 $Y$ での近寄り流れの流 速 $U$ は $U_{0}$ より小さく式(2)から求まり，さらにその $Y$ での買素まわりの流れが二次元重まわりの流れと 相似であると仮定する。すると，

$$
\int_{0}^{1} \frac{p-p_{0}}{\frac{1}{2} \rho U^{2}} d\left(\frac{\xi}{C}\right)=C_{N 2}
$$

となる。一方,

$$
\begin{aligned}
& \int_{0}^{1} \frac{p-p_{0}}{\frac{1}{2} \rho U^{2}} d\left(\frac{\xi}{C}\right)=\int_{0}^{1} \frac{p-p_{0}}{\frac{1}{2} \rho U_{0}^{2}} d\left(\frac{\xi}{C}\right) \cdot\left(\frac{U_{0}}{U}\right)^{2} \\
& \quad=C_{N} \cdot\left(\frac{U_{0}}{U}\right)^{2}
\end{aligned}
$$

となる、それゆえ，境界首内にある具索の圧力係数 $C_{N}$ は，迎え角によらず次の式（）で与えられる。

$$
\frac{C_{N}}{C_{N 2}}=\left(\frac{U}{U_{0}}\right)^{2}=\left(\frac{Y}{\delta}\right)^{1 / 4}
$$

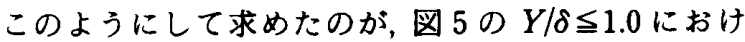

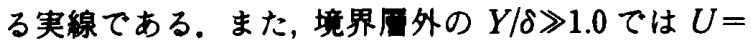
$U_{0}$ となるため, $C_{N} / C_{N 2}=1.0$ となる。

$\alpha=4^{\circ}$ の実測值 $C_{N} / C_{N 2}$ は，側壁面のごく近くでは 流れが複嚾となり実線と一致していないが，側壁面か

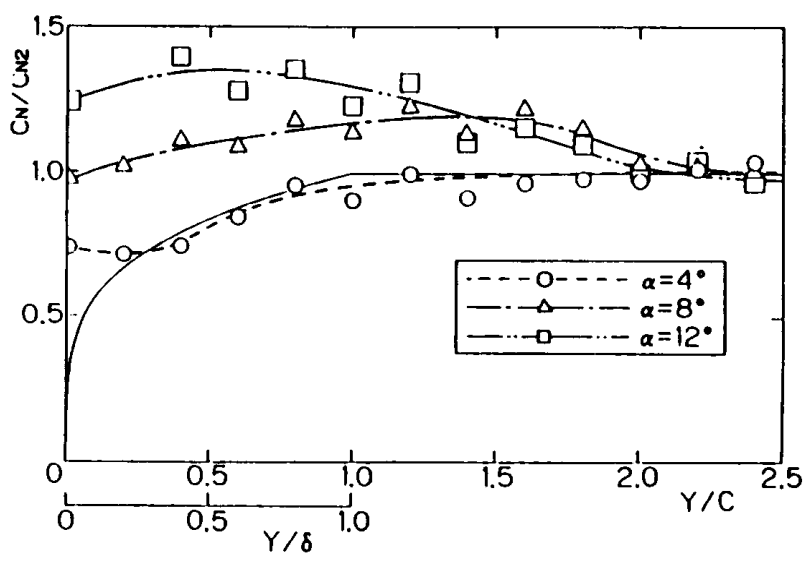

図 5 圧力保数のスパン方向分布 
ら離れるにつれて実線に比較的よく浻って増加してい る、それゆえ,ここでは先の仮定のような流れが実現 していると思われる. $\alpha=8^{\circ}$ の $C_{N} / C_{N 2}$ 值は，側壁面か ら離れるにつれて $Y / C=1.7$ まで增加し，その後は 徐々に減少して 1 になる。 $\alpha=12^{\circ} の C_{N} / C_{N 2}$ 值は, 最
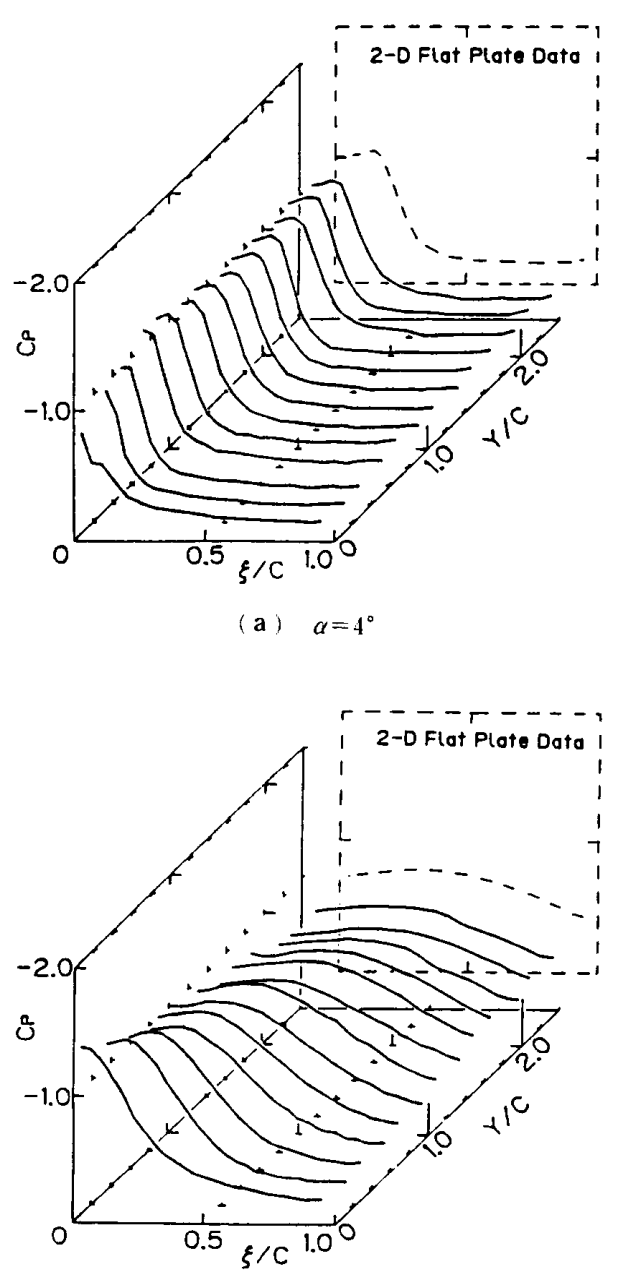

(b) $\alpha=8^{\circ}$

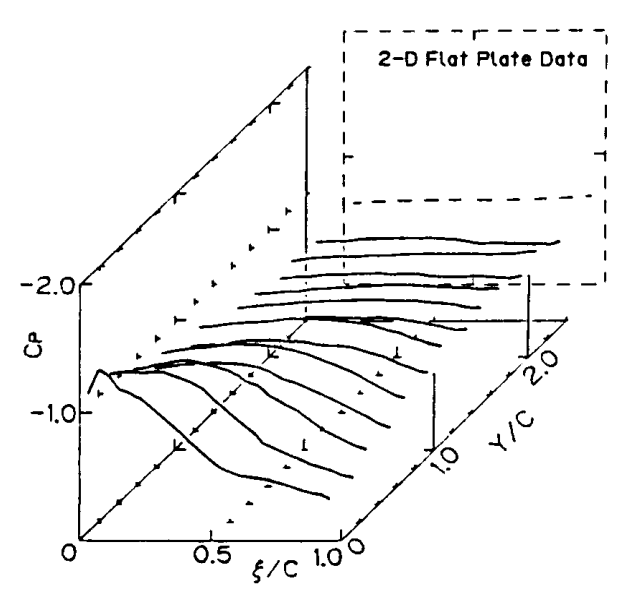

(c) $a=12^{\circ}$

図 6 負圧面上の圧力分布
初から二次元翼での值を大きく上回っており，側壁面 から離れるにつれて增加し， $Y / C=1.0$ 以上では次第 に減少して 1 に渐近している，普通に考えると，境界 層内にある翼素の局所の圧力係数は境界層外のものに 比べて小さいと推測されるのに，図 5 では，境界居内 の翼素の $C_{N}$ は $C_{N 2}$ 値を超えている。このようなこと が生じた原因を, $3 \cdot 3$ 節で調べる.

$3 \cdot 3$ 压力分布図6に，3種の迎え角における 翼負圧面上の翼弦方向の圧力分布を $Y / C \fallingdotseq 0.0 \sim 2.4$ について示した，図6 中のいちばん奥の点線は, 二次 元翼での圧力分布を示している。

$\alpha=4^{\circ}$ の図6（a ）では， $Y / C=2.0$ の圧力分布は点 線で示した二次元翼とほぼ同じである。前緑はく離で 圧力が一定な領域 $(Y / C=2.0$ では $0.0 \leqq \xi / C \leqq 0.2)$ は， 翼根元に近つくくに従って狭くなる，この原因は，次の ように考えられる(以下図 7 参照).

側壁面上の境界層内では，紧のスパン方向の速度分 布があるため右ねじ方向の渦が存在する。この渦を 1 本の渦系で考える。この渦禾が平板基前緑に衝突する と，翼正圧面側で左妨じ方向の，翼負圧面側で右ねじ 方向の流れが誘起される(図 7 の流れC)。翼負圧面側 で誘起された右ねじ方向の流れにより，負圧面上方の 主流の持つ運動エネルギーがはく踓域内に流入し，翼 表面の流れのはく離が抑えられる。また，主流の側壁 面上の静圧 $p_{0}$ と翼負圧面上の静压 $p$ の大小を比べる と $p_{0}>p$ であり，特に前緑付近では顕著である。この 圧力差により，側壁面から翼負圧面の根元を経て翼端 へ向かう流れが誘起される。をれを図 7 の流れ $\mathrm{A} ， \mathrm{~B}$ で示した。 $\mathrm{A}$ は，側壁面の境界層の底近くの流体が基 表面の流れがはく離している領域へ流入した流れを示 し，Bははく雕していない領域に流入した流れを示

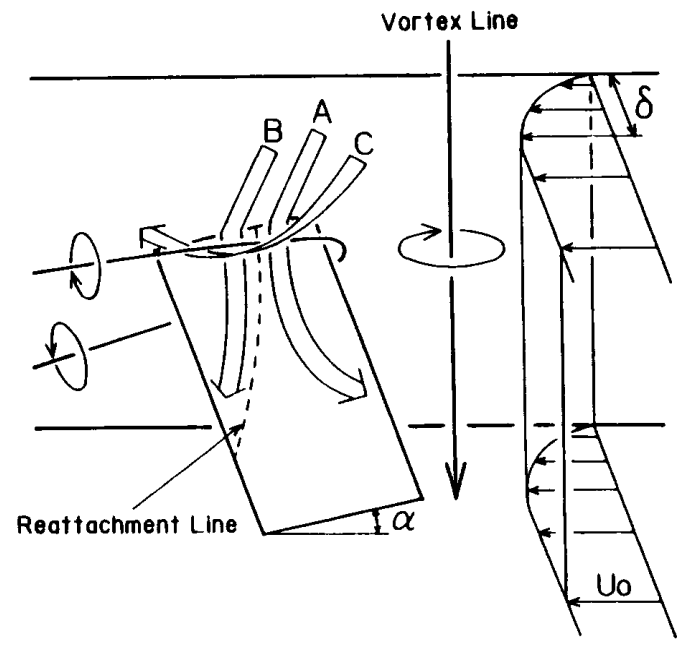

図 7 筫根元における二次流れ 
す.これら $\mathrm{A} ， \mathrm{~B} の$ 流れにより，翼負圧面上のはく離し た流体が運び去られる。これら 2 種の流れにより，流 れのはく離が抑えられ，前述したようなことが現れた と推察される。

また，翼根元に近づくほど，綐軸 $\left(C_{p}\right)$, 横軸 $(\xi / C)$, および圧力分布線で囲まれる面積が小さくなってい る。これは，境界層内では側壁面に近づくほど近寄り 速度 Uが小さくなっているためである.

$\alpha=8^{\circ}$ の図 6 (b)では, $Y / C=2.2$ の圧力分布は二 次元翼とほほ同じである。前縁からはく離して, 圧力 が一定な領域は，翼根元に近づくほど狭くなる．そし

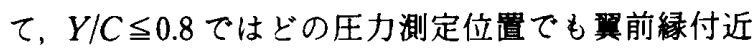
で圧力はかなり低下しており，翼後縁に近づくにつれ 圧力が回復し，翼後緑付近で圧力こう配がなめらかに

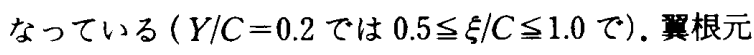
に近づくほど先ほど述べた理由によりはく離が抑えら れるためにこのような圧力分布になったと考えられ る.

$\alpha=12^{\circ}$ の図 6 (c) では, $Y / C=2.2$ の圧力行布は二 次元翼とほほ同じである，圧力が一定な領域は，幊根 元に近づくに従い $Y / C=0.4$ で $0.0 \leqq \xi / C \leqq 0.3$ と狭く

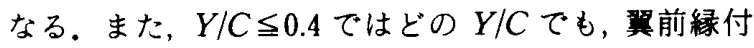
近で圧力がかなり低下し，翼後緑に近づくほど， $\alpha=$ $8^{\circ}$ の場合ほど急激ではないが, 圧力は回復している。

このことから，翼根元付近では流れのはく離が抑えら れていると判断できる。

前述したように,この 2 種の二次流れは翼表面の流

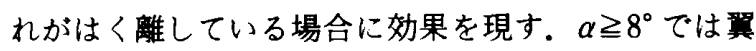
弦方向全領域にはく離域が広がっていて，乵根元付近 では，これが抑制されることにより，図 5 において， $\alpha$ $=4^{\circ}$ よりも $\alpha=8^{\circ}, 12^{\circ}$ のほうが翼根元付近の $C_{N}$ 值が 著しく $C_{N 2}$ 值を超えたと考えられる.

$\alpha=8,12^{\circ}$ の $Y / C=0.007$ で, 置前縁付近の圧力が接 合部分のごく近辺にもかかわらずかなり低下してい る.これは，次のことによると推察される.買負圧面上 のはく離泡内の流れは，翼表面近くでは前縁に向かっ て流れ，前緑付近では翼表面からはく離泡内の上部に 向かい, そして下流方向へ流れる。このようにはく離 泡内の流れは渦巻いており，この渦巻の大きさ（はく 離泡の大きさ）は，墨根元から $Y / C$ が大きくなるに伴 い翼負圧面前半部から翼弦方向全域に広がる。そして， これに図 7 のの流れが加わる.このように,はく離 と二次流れによって翼根元前緑からスパン方向へ童巻 状の渦が生じており，この竜巻状の渦心により翼根元 付近の圧力がかなり低下したと考えられる。

\section{4. スモークワイヤ法}

翼負圧面側根元付近では, 境界居内の速度分布によ る渦禾により誘起された二次流れ，側壁面上と買負圧 面上との静圧の差により誘起された二次流れ，それと 翼根元前縁からスパン方向への竜巻状の渦の存在を推 測した。これらの流れが本当に存在するか否かを確か めるため, 翼根元の負圧面付近の流れの様子をスモー クワイヤ法を用いて観察した。その際, 流速は煙の覵 察が明りょうに行えるよう $U_{0}=1.5 \mathrm{~m} / \mathrm{s}$ とした。それ ゆえ,レイノルス数は翼表面の圧力分布測定時よりも 1 けた小さくなった。そのため, 翼設定位置の境界首 厚さは約 $80 \mathrm{~mm}$ となり，また，翼性能も低下する。し かし，翼根元付近の流れの様子は，定性的にはあまり 変わらないと思われるので, スモークワイヤ法で流れ

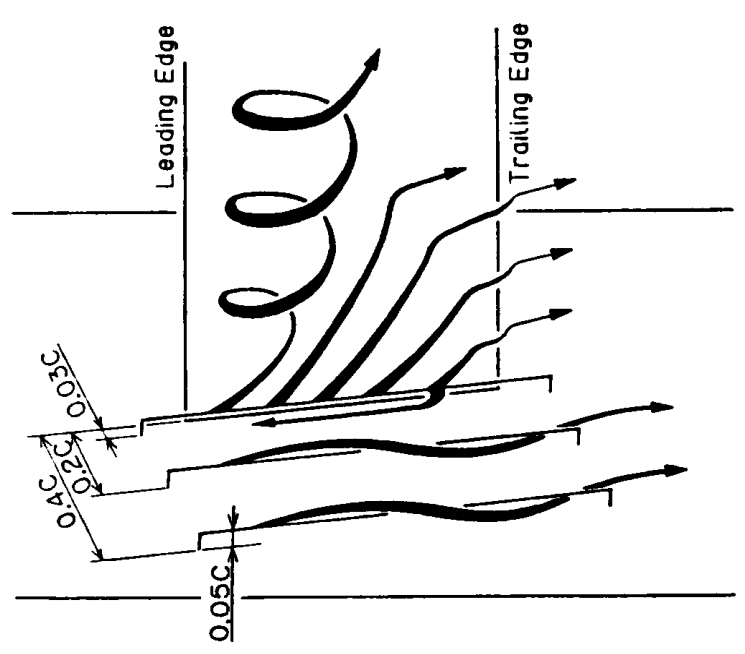

(a) 煙線高き $Y=0.05 C$

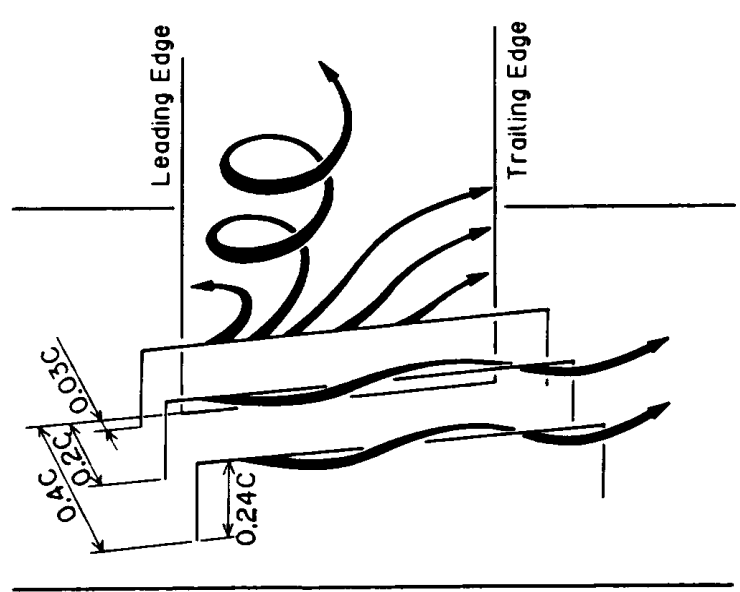

(b) 煙線高 $Y=0.24 C$

図 8 翼負压面の翼根元付近の流れ ( $\alpha=8^{\circ}$ の場合) 


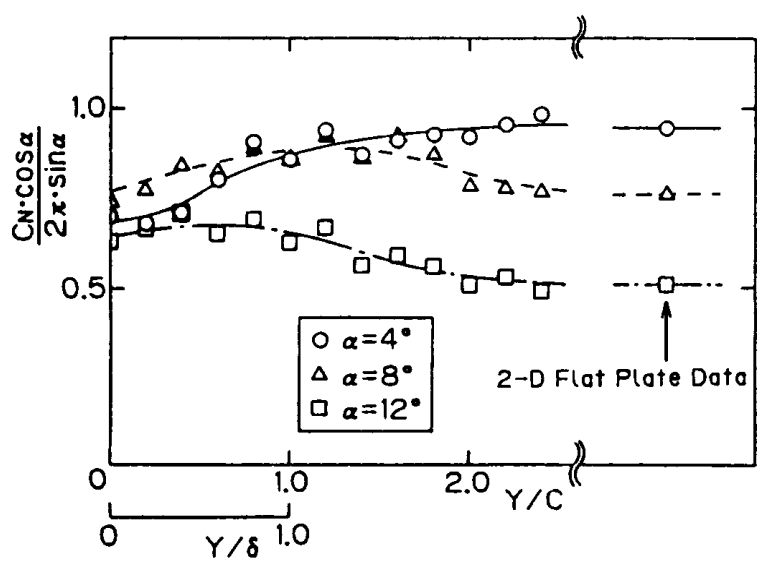

図 9 掝力係数の回復の程度

を涀察した。流れの覞察は，迎え角 $\alpha=8,12^{\circ}$ で行っ た.スモークワイヤは, $Y=3,15 \mathrm{~mm}(Y / C \fallingdotseq 0.05$, 0.24）において具負圧面から $\eta=2,12,24 \mathrm{~mm}(\eta / C \fallingdotseq$

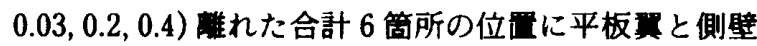
面の両方に平行に個々に設置した。そして，それぞれ の位置で個々に煙を発生させ，その流れの様子を钼察 しスケッチした。ここでは，迎え角 $\alpha=8^{\circ}$ のものを図 8 に示す。

（1）側壁面近くの流れ $(Y=0.05 C)$ 基負圧面 からかなり嚾れた $\eta=0.2 C, 0.4 C$ では[図 $8(\mathrm{a})]$, 煙 は主流方向よりも䆬負圧面のほうへ少し奇って後方へ 流れた。これは，側壁面との圧力差によって誘起され た二次流れが存在していることを示している，罢負圧 面に近接した $\eta=0.03 C$ で，置根元前縁から巻き起 こる竜巻状の渦が嚾察された。また，負压面後半部 での煙の流れは，翼負压面に治って少しスパン方向に 向かいながら, 後方へ流れた.このことから, 翼根元付 近の流れは，置後半部ではく鹤することなく流れてい ることがわかる。

（2）側壁面から噰れた領域 $(Y=0.24 C)$ 罢負 圧面からかなり噰れた $\eta=0.2 C, 0.4 C て ゙ は$ 図 8 (b)]，煙は側壁面上の境界展内の速度分布による渦 禾により誘起された流れに乗り左巻きに後方へ流れ た。輩負圧面に近接した $\eta=0.03 C$ では，煙は負圧面 前半部で置根元前緑から続いている童巻状の渦の流れ に乗りスパン方向に巻き上げられた，負圧面後半部で は負圧面に治って後方へ流れ， $Y=0.24 C$ でも買後半 部で流れははく蹃することなく流れていることがわか る.

$\alpha=12^{\circ}$ のスケッチはここでは示していないが, $\alpha=$ $8^{\circ}$ の場合とほほ同様の二次流れが敏察できた。

\section{5. はく維防止の程度}

曋根元の境界届内の速度分布による洞禾および側壁 面上と買負圧面上との静圧の差により誘起された二次 流れが、はく噰をどの程度抑えているかを図 9 に示 す.

図 9 中の繸軸は, 実湖值 $C_{N}$ から求めた揚力係数 $C_{L}\left(=C_{N} \cos \alpha\right)$ を二次元平板霓理論から莩いた完全 にはく離のない状䈍での揚力係数 $C_{L}=2 \pi \sin \alpha て ゙$ 除 した值を表す．図 9 中の右端のデータは，境界届の影 製が及ばない場合の二次元平板置での実测值である。 $\alpha=4^{\circ}$ の $Y / C \leqq 1.0$ では，境界四内速度分布のため 揚力係数は理論值とは一致しないが，それ以外の領域 では，理論值にかなり近ゔいている， $\alpha=8^{\circ} の 0.6 \leqq$ $Y / C \leqq 1.8 て ゙ は ， は く$ 離が抑えられているため揚力係 数は理論値の $80 \%$ \%をで近づいている. $\alpha=12^{\circ}$ の 0.0 $\leqq Y / C \leqq 1.4 て ゙ は ， は く$ 離が抑えられているが、はく 唯のない理想的な状怎と比較すると，掦力係数は最大 その $70 \% に し か$ 到達しておらず，図 5 では $C_{N} / C_{N 2}$ 值は 1.2 を超えていたが，買性能はさほど向上してい ないことがわかる。

\section{6. 結}

本研究では，航空機などの胴体の境界届が罢性能に どのような影零を及ほすかを調べるため，基本的な鿓 形である平板罢を用いて其表面の圧力分布を群練に測 定し，また，根元付近の流れの様子をスモークワイ ヤ法を用いて観察した。その結果, 次のことがわかっ た。

（1）迎え角が小さく累負圧面側で流れがあまりは く離していない場合，境界田内の $C_{N}$ は近寄り流れの 大きさが主流より減少することを考虑した式(3)でほ ほ推測される，しかし，迎え角が大きくなり買負圧面 側の流れがはく㫿している場合は， $C_{N}$ は境界四内に もかかわらず，また，近寄り流れが主流より幄いにも かかわらず二次元置の $C_{N 2}$ より大きい值を示すこと がある。

（2）この原因は，境界冨内の速度分布による渦禾 により誘起された二次流れ，および，側壁面上と罢負 圧面上との静圧の差により誘起された二次流れがはく 唯を抑制したためと判断される。それゆえここらの 二次流れにより買性能が向上する器は, 元来流れのは く離により置性能が悪かった置であると推測される。

（3）罾負圧側の猉根元前緑からスパン方向に竜巻 状の強い渦が生じているのが煙線法により観察され た。 
文

棫

（1）田中・ほか 2 名，機論，43-369(1977)， 1786.

(2) Coles, D.. J. Fluid Mech., 1-1(1956), 191.
（3）日本流体力学会編, 流体力学ハンドフック(1987)，233，丸 普.

(4) Lamb H., Hydrodynamics, 6th ed.. (1963), 103, Cambridge at the University Press. 